\title{
Factors Affecting Some Failure Arab States Uprising and Obstacles for Development
}

\author{
Ibrahim M. A. Alfaggy \\ Institute of Diplomatic Studies, Riyadh, Saudi Arabia
}

\begin{abstract}
Some Arab states witnessed a number of uprising, which ranged from violent reactions toward their people, such as in Syria, Libya, Egypt, and Yemen, while some countries were trying to prevent these revolutions by using different measures, in which can be described as "cosmetic surgeries", such as Morocco and Tunisia. There are a number of factors, which leads Arab states to what is known "the failed state". These states for more than three decades had failed to achieve a minimum of political stability, well-being, economic, and social development for their people, to keep up with global changes in political, economic, and social reforms. Some political factors affecting Arab uprising, including lack of political reform, democracy, human rights violations, illegitimate governments, and absence of anti-corruption policy. Arab states governments had failed to achieve the minimum requirement of economic development, to solve economic chronic difficulties in transitional economies, in fields, such as food and water security, human resources development, and economic development at local and regional levels. In addition, there are social factors ignite the Arab uprising. Including high rate of unemployment, deterioration of industrial and agricultural sectors, uncontrolled migration to cities consequently increase pressure on social services and economic development of cities.
\end{abstract}

Keywords: Arab revolt, factors, obstacles, politics, economy

Most researchers on Middle East have agreed that there are a number of problems that led to the ignition of Arab revolutions, including the dictatorship, widening gap in income inequality, high unemployment rates, collapse of infrastructure and services, and high commodity prices, particularly subsidized ones. Arab regime either monarchy, or Republican, it is difficult to determine the differences between these regimes. They are consistent in being absolute authority, seeking to stay forever through the violent repression of revolutions, as these systems have remained in power for several decades through use of military force to stay in power depending on their families, their tribes, ethnic, or religious doctrine. In addition, these regimes are characterized by injustices, cruelty, and corruption. To maintain their personal interests in their countries and their peoples, through prevention of opposition, freedom of speech, expression, and opinion, a threat must be prevented during these revolutions against Arab leaders, where some of whom escaped, others stepped down from power and others are still fighting against their own people, as Yemen, Libya, Syria, Tunisia, and Egypt. While some Arab rulers worked to put temporary solutions to absorb the resentment of people on them, such as Jordan, Lebanon, Morocco, and Algeria, these countries were on the brink of revolutions.

Corresponding author: Ibrahim M. A. Alfaggy, Ph.D., associate professor, Political Geography, Asian Studies Center, Supervisor of Institute of Diplomatic Studies, Saudi Arabia; research fields: political geography, water resources, and geopolitics. E-mail: ifaggy@yahoo.com. 


\section{This Research Aim Is to Answer These Important Questions}

(1) What was the aim of Arab spring protests?

(2) What factors are affecting the emergence of Arab uprising phenomenon?

(3) How the Arab uprising of 2011 change the region and its peoples?

\section{Are the Arab Uprising States Failed States}

The Fund for Peace and the Carnegie Endowment created a global ranking of 60 weak and failed states using 12 indicators: demographic pressures, refugees and displaced persons, group grievance, human outflow, unbalanced development, economic collapse, de-legitimization of governments, public services collapse, human rights violations, failed security apparatus, elite dominance, and external intervention. The resulting index shows some of Arab failure states such as Sudan, Iraq, Somalia, Yemen, Syria, Egypt, and Libya (Failed States, The 2013 Index, The Annual Edition).

According to Ryan (2007, pp. 53-54), there are many signs of failure states in which can be applied to some Arab states such as: poor governance, weak central governments, law lessens, unsecure borders, spread of local and regional conflicts, conflict within the failure state, high growth of population, high rate of unemployment, ageing dictatorship, and corruption.

\section{Factors Affecting Some Arab States Uprising and Obstacles for Development}

\section{High Growth of Population}

Most Arab Middle East countries witnessed high fertility rates. Where these countries had reached an average of least $50 \%$ of population is under age of 25.2. In addition, the Middle East's average unemployment rate is $10 \%$, higher than any other region in the world, and rapid population growth is not accompanied by similar economic growth (Al Sharekh, 2011, p. 52).

Since the 70s of the last century, population in Egypt has doubled, the elite control the Egyptian economy, while rest of population, more than $40 \%$ of the total population is suffering from poverty and high unemployment. Low quality of education, weak political participation, and absence of national projects raise the peoples' national enthusiasm and interaction (Egypt's Uprising, 2011, p. 7).

\section{Collapse of Arab Economies}

In Egypt, tourism as an economic revenue reportedly dropped by $75 \%$. When Mubarak resigned, more than $20 \%$ of Egyptians were living below the poverty line. They expected a measure of prosperity after he left, but instead, their plight worsened. No country now in transition will be able to accommodate demands for either economic security or social justice soon. One hundred million people - one-third of the Arab world — are in job-hungry age range from 15 to 29 years old. Many countries may face a second crisis, or even a series of crises (Wright, 2011, p. 58).

Over the past decades, these countries have taken some steps to liberalize their policies on privatizing theirs public sectors and institutions, but liberalization phenomenon linked with corruption, particularly from the ruling families and elites, who benefited from advance information on economic policies of privatization, obtaining big financial gain in a real isolation from their own people. In Tunisia, for example, knowledge contributed many benefits to the ruling family of Ben Ali, and his relatives, including his government were going on in acquisition of the capabilities of Tunisia in various economic sectors. 


\section{Corruption}

An important factor driving the protesters in Arab Spring countries, as a motivation, corruption including money laundering, corruption charges, recent privatization efforts, with charges fostered the growth of crony capitalism, and possible graft, probes into oil concessions (Vaughan, 2013, pp. 500-501).

In 2006, these families took over half of the contracting sectors through relationship of kinship and affinity. In Egypt, Ahmed Ezz, a member of the ruling party, had benefited from his position in the ruling National Democratic Party and his friendship with Jamal Mubarak in controlling of about $60 \%$ of the steel sector in Egypt. These policies have contributed to increase in anxiety and fear among working class and increase unemployment and fear within contracting sector (Cole, 2011, pp. 5-6).

Ben Ali of Tunisia ruled his country about 23 years, and the unemployment rate reached about $42 \%$ of total population of 10 million. Wealth of Tunisia is controlled by Ben Ali, his family, and those who are close to him, his total fortune is more than $\$ 3.2$ billion, half of Tunisian economy is controlled by the Tunisian elites. Elite groups including Ben Ali and his family, were controlling the trade and buying companies and real estate, accompanying with corruption and police force numbered about 80,000 men people (Ismi, 2011, p. 16) (see Figure 1 and Table 1).

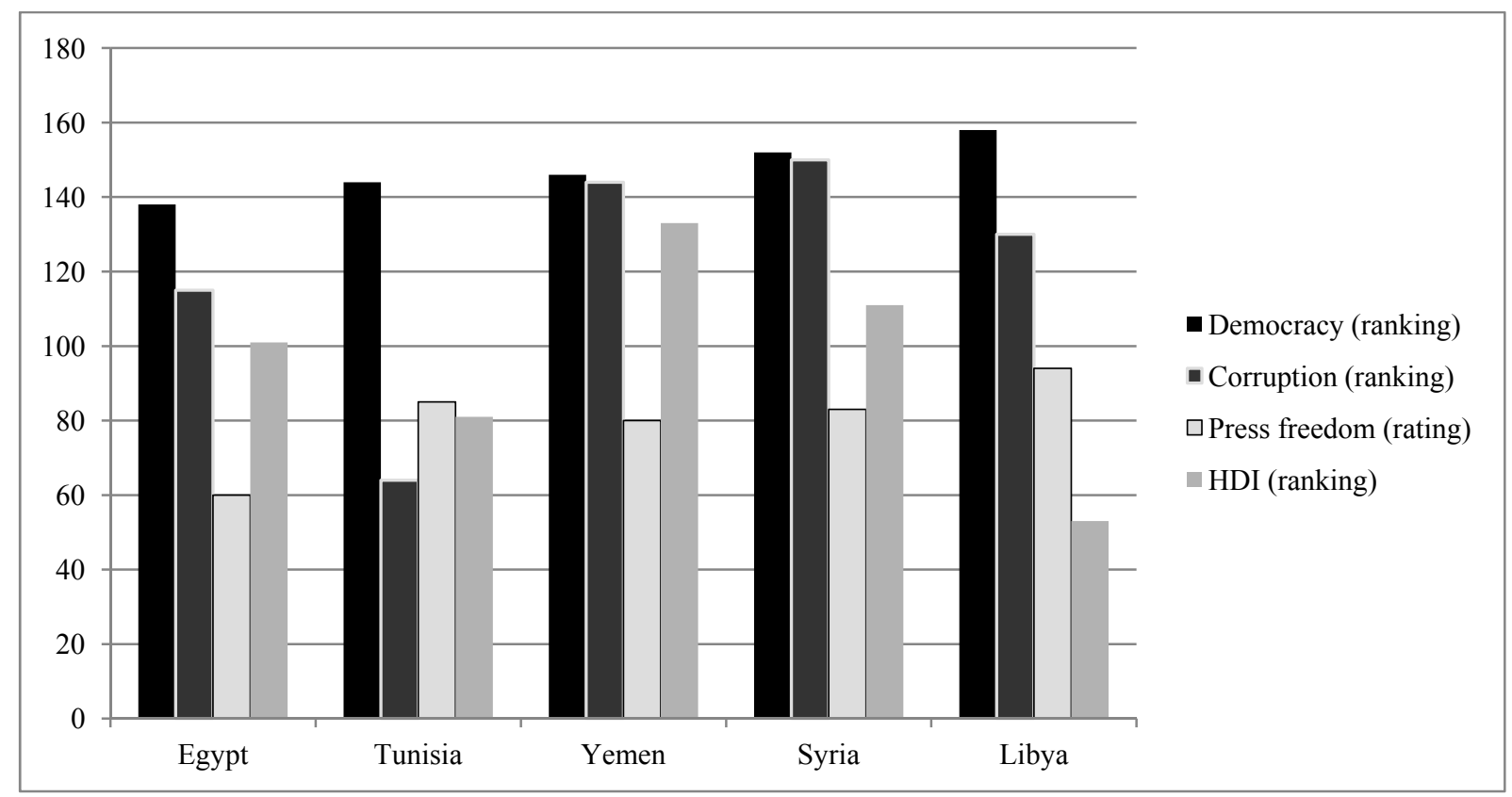

Figure 1. Relations between democracy and corruption in some Arab states. Source: Behr and Aaltola (2011, p. 5).

Table 1

Democracy, Corruption, Human Development Index Ranking and Press Freedom Rating

\begin{tabular}{lllll}
\hline State & Democracy (ranking) & Corruption (ranking) & Press freedom (rating) & $\begin{array}{l}\text { Human Development } \\
\text { Index (HDI) (ranking) }\end{array}$ \\
\hline Egypt & 138 & 115 & 60 & 101 \\
Tunisia & 144 & 64 & 85 & 81 \\
Yemen & 144 & 140 & 80 & 133 \\
Syria & 152 & 150 & 83 & 111 \\
Libya & 158 & 94 & 53 \\
\hline
\end{tabular}

Note. Source: Behr and Aaltola (2011, p. 5). 


\section{High Rate of Unemployment}

Unemployment is among protester's key factors, as job creation with the region's fast population growth, and has been a chronic mismatch on the education that is providing skills that job market needs. Despite the dramatic oil boom of 2003-2008, and increases in public spending, economic inequality is on the rise in many Arab countries, where high inflation eroded the low wages of the poor and the "unskilled". Unemployment is high even in countries with plentiful jobs, like those in the Gulf, which are increasingly dependent on foreign workers because of the weaknesses of education systems. In Gulf States, incentives to work and study are limited by systems that are seen as rewarding personal connections, family relationships, and political loyalty more than hard work. For example, to meet its economic developments, Egypt needs to create 700,000 jobs per year just to keep unemployment stable. Reducing unemployment will require growth rates of around $7 \%$ (Kinninmont, 2011, pp. 31-33).

In fact, high rate of unemployment among young people, rapid population growth, and defective economic structure, other industries remained underdeveloped and unable to provide a solid base for job growth (Mei, 2011, p. 10).

About half of Egypt's population live on less than two dollars a day; in addition, about $50 \%$ of total population suffer from unemployment. During the reign of Mubarak, the Egyptian Government privatized a number of public sector companies in accordance with the requirements of the International Monetary Fund (IMF), during the 1990s, an action had increased unemployment, corruption, and labor unrest, which is one of the key factors lead Egypt to January 25 Revolution and peoples claimed to raise wages and improve their social conditions (Ismi, 2011, p. 17).

Yemen, Libya, and Palestine, where unemployment exceeds 30\%, have seen further political upheaval, as Egypt and Tunisia are examples inspiring locals to continue to press for real change (Al Sharekh, 2011, p. 52) (see Figure 2 and Table 2).

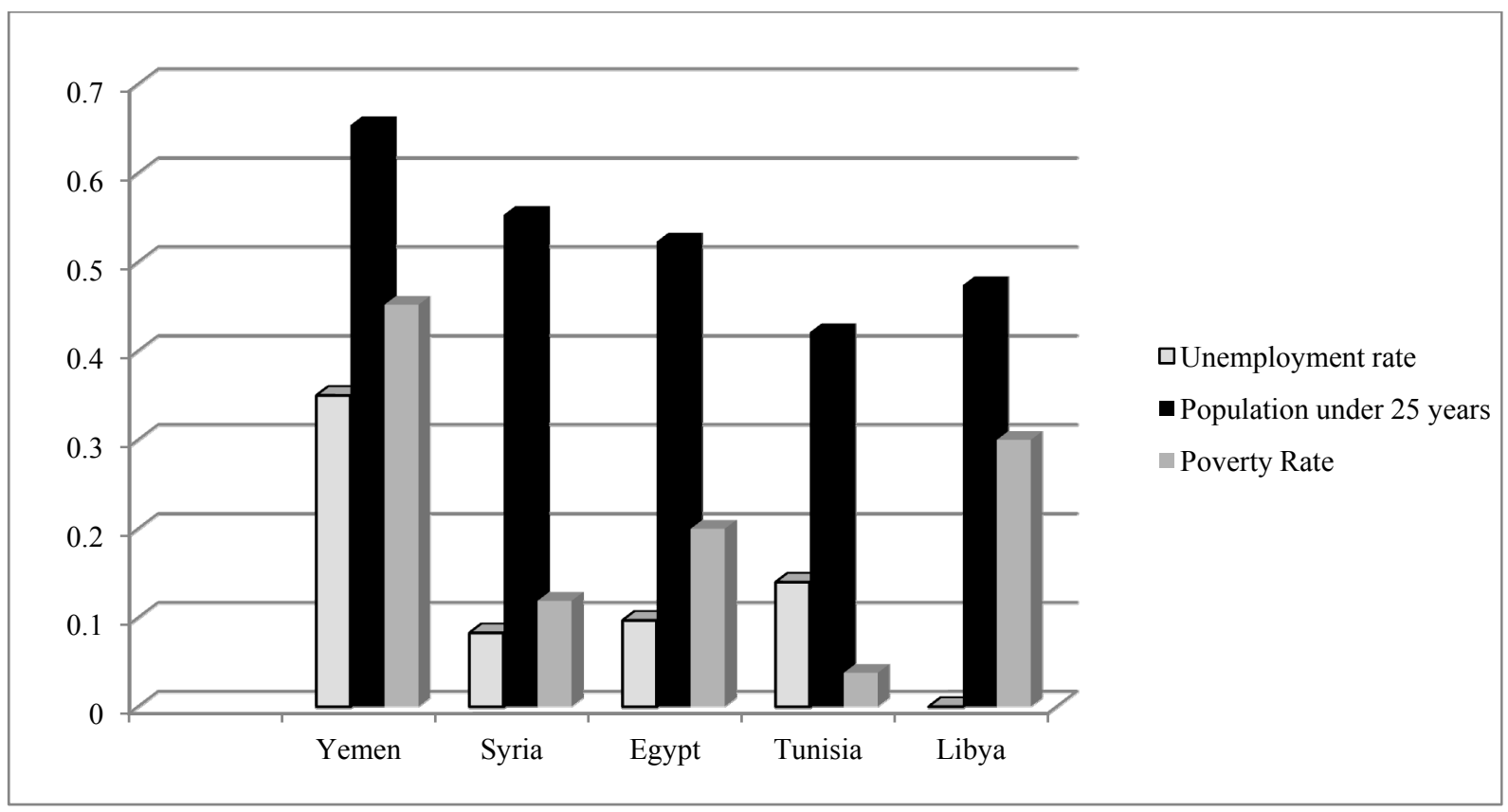

Figure 2. Population and unemployment. Source: Behr and Aaltola (2011, p. 4). 
Table 2

Population, Unemployment, and Poverty Rate in Some Arab Failures States

\begin{tabular}{llllll}
\hline State & GDP/capita & GDP growth & Unemployment rate & Population under 25 years old & Poverty rate \\
\hline Yemen & 2,900 & $6.2 \%$ & $35.0 \%$ & $65.4 \%$ & $45.2 \%$ \\
Syria & 4,730 & $4.0 \%$ & $8.3 \%$ & $55.3 \%$ & $11.9 \%$ \\
Egypt & 5,860 & $5.1 \%$ & $9.7 \%$ & $52.3 \%$ & $20.0 \%$ \\
Tunisia & 8,620 & $3.4 \%$ & $14.0 \%$ & $42.1 \%$ & $3.8 \%$ \\
Libya & 18,720 & $3.3 \%$ & Not available & $47.4 \%$ & $30.0 \%$ \\
\hline
\end{tabular}

Note. Source: Behr and Aaltola (2011, p. 4).

\section{The Spread of Local and Regional Conflict}

Problems in Yemen have its own aspects, in which factors increased the start of the revolution including big difference of social, economic, and cultural in Yemeni society. In addition, differences among tribes of North and South Yemen, where South Yemen was forced to unite with the North. In addition, the religious differences between the northern part of North Yemen, where rebels and Islamist extremists in the countryside of North Yemen, the chronic problems of oil production reduction, Yemen water crisis, and finally high inflation in the public sector (Cole, 2011, p. 6).

Yemen is facing many problems, which including, poor people in Yemen, about 10 million people, if this number, one third of workforce in Yemen are unemployed, half of the overwhelm population are uneducated, per capita income is estimated between 650-800 dollars. In addition, the spread of tribal violence, the weakness of law enforcement on the outskirts of the state, unsafe political boundaries, the spread of the arms trade and kidnappings, terrorism and Yemen politically split between North and South and unlawful across the border with neighboring countries, which is an attracted aspect for job search opportunities in these countries (Ryan, 2007, p. 52). Besides, flow of refugees, increasing level of narcotics trafficking and conventional weapons proliferation. All these factors are making Yemen a unique case of Arab failure state.

\section{Social Injustice}

Social injustices is one of many factors that lead to the revolution in Egypt, the social status of the state, which has a population of about 90 million people, $50 \%$ of them tend to be uneducated. The social level including the economic level of the majority of population of the Egyptian society, or about $90 \%$ of the total population, is getting poorer with a sharp decline in standard of living and capability to get jobs. A small percentage of population is with high economic status, or closer to the Western life (Nkrumah, 2011, p. 10). For example, Yemeni women are married before the age of 18, and the average number of children born is about seven children, which means that the population of Yemen up to double in 2030, increasing pressure on the limited resources of Yemen (Ryan, 2007, p. 57).

\section{The Role of the Modern Media}

Social media networks played an important role in rapid decay of at least two regimes, Tunisia and Egypt, while contribution to the socio-political mobilization in Bahrain and Syria.

According to the Egyptian Department of Communications and Technology Information (MCIT), the country has more than 17 million internet users (2010, February), an increase of $3.6 \%$ by 450,000 users in December 2011, and 4 million users of Facebook. This amount includes more than 160,000 bloggers with 30\% of blogs focusing on politics. Social media plays a very important role in Arabs countries, because it is an ideal tool to connect free networks association, which otherwise brings together, different groups and individuals for 
a common cause (Khan, 2012, p. 57).

Arab revolutions have indicated the possibility of non-violent revolutions, as it had happened in some Western countries, which have a legal power status of democracy, and ability to bring a radical change in Arab dictator regimes, that do not hesitate to torture and murder of opponents, who are claiming their rights. The advancement in modern media had raised fears among Arab dictators of growing impact on attitude of Arab peoples, especially young Arabs (Wambu, 2011, p. 15).

Cortright $(2011$, p. 7) points that four factors led to the success of the revolutions in both Tunisia and Egypt: (1) large number of masses; (2) demonstration of peaceful movements; (3) solidarity between masses and military; and (4) direct effective of social media.

Facebook, for example, has contributed several ideas and discussions to the democracy. At the beginning of the revolution on January 25, Mubarak regime, felt the influence of modern media, including Facebook, so the regime cut off the internet network, mobile phones, Twitter, Facebook, and SMS service, which prevented communication from youth (Darwish, 2011, p. 14).

During January 25 Revolution in Egypt, Google and Twitter had allowed the demonstrators to send their messages even after the Egyptian authorities cut off the internet. Media such as Al-Jazeera plays an important and key role in the occurrence of revolutions and success. For example, it has contributed to the deployment of picture of revolution via world TVs (Suarez, 2011, pp. 31-32).

WikiLeaks played a key role in igniting the revolution in Tunisia when leaked information about thefts carried out by ousted President Zine El Abidine Ben Ali (Wiki Leaks Was Spark to "People Power" Uprising in Tunisia, 2011, p. 2).

Mobile phones, SMS, and MMS are all influencing technology roles to reach people all over the world. In the past, organizing a revolution, it has to be a personal and secret meeting on a small scale, while today, events such as those people have seen, they can be organized in a few days, with a unique contribution that each person can introduce himself easily in every minute (Khan, 2012, pp. 60-61).

\section{The Emergence of New Personalities}

Arab revolutions witnessed the emergence of a number of national icons, who played a prominent role in events, or during the revolutions. New names have appeared for the first time in Arab uprising, while in the past names in revolutions are those, in which belongs to leaders in the military, or politicians. For the first time in Arab countries, names of ordinary people appeared, and become icons of these uprising. There was the Tunisian Mohamed Bo Azizi, and the Egyptian Khalid said who was appeared in Arab Streets, as a symbol of heroism and sacrifice. Twakol kerman from Yemen, Dr Mohammed al-Bradi are both Noble Prize winners.

\section{The Religious Factor}

The rise of the Muslim Brotherhood is likely to reveal an unsurprising desire for religion to play a greater role in post-Arab spring states. These trends offer a ground for future tensions between those who would like to see a secular, democratic state in a Western style, and those who would prefer their new state to be governed by Islamic law (Williams \& Popken, 2012, p. 49).

\section{Women's Role in the Uprising (Women's Participation and Equality)}

The phenomenon of inequality among sexes, generations, and human development are of many factors that led to the unrest in the Arab region. To ensure a better future, the promotion of equitable human development should rely on reducing imbalance between sexes (Human Development Report, 2011). 
Women participated in protest movements have rocked the Arab world in 2011. They are demanding freedom, equality, justice, and democracy, looking for full part to do their full part in building the future of their country, through participation in public and political life on an equal basis with men (Federation International des ligues des droit de I'Homme [FIDH], 2012, p. 80).

For example, there were no women in two committees nominated for drafting a new constitution in Egypt. The new electoral law measures are ensuring a minimum participation of women in parliament, and women gained only $2 \%$ of seats in the recent elections. In Libya, the electoral law adopted by the National Transitional Council (NTC), does not include share of women's representation in elected bodies. In Morocco, the established law, which was adopted in 2011 October, women's representation was amounted only 15\% quota and there is one-woman minister in the cabinet of 30 members (compared to seven in the previous government). In Tunisia, there are 41 members of the government, the number of women are only three (FIDH, 2012, p. 81).

Impact of Arab Spring is not only on young people, but also extends its influence to Arab women's movement. Women in Arab countries have affected by the weakness of unequal participation within the labor force, in addition to the low educational achievements.

The issue of women's rights and women role could play in rebuilding their nations and reshaping their future, it is a key part of the uprising. There is a lot of disagreement in countries such as Egypt on the potential implications of Arab Spring on the future of Arab feminist movements and it expected not to gain for Arab women at large.

On one hand, there are optimists, who count on Arab women's resilience and determination for change and considering them to be the best protection against any possible backlash against women's rights. These young Arab women reflect the pulse of a new generation of women activists who see no limits to women's achievement in the rapidly changing Arab world (Khamis, 2011, pp. 692-693).

On the other hand, for example, community of women in Egypt is a conservative society. Since 1995, participation of women in the Egyptian parliament, the number of the total seats is less than $\%$, compared to the status of women in Turkey, Iran, Tunisia, and Morocco. Egyptian women could not involve causing changes in Egyptian society.

During January 25 Revolution in Egypt, hundreds of thousands of Egyptian women came down to Tahrir Square in Cairo, expressing their solidarity with the revolution, taking advantage of International Women's Day and aim of sending a message and a clear desire to make social and cultural changes, role of women in a dignified life. Egyptian revolution in female part returns to a number of external and internal factors, external factors including:

(1) Role of women in searching for social and legal status before the revolution;

(2) Role of social mobility, particularly number of organizations and institutions;

(3) Role of ideas and value, that came out of the revolutionary movement or new government prospective;

(4) The ability of expected new state to employ their resources for development.

Tunisian women played an important role in the economic life in Tunisia. Number of university graduates increases accounted for $60 \%$ and makes up about $50 \%$ of the category of population aged less than 25 years, and more than $40 \%$ of the unemployment rate of labor force in Tunisia (Lancaster, 2011, p. 19).

\section{Environmental Factors}

Human development faces a number of major environmental challenges, including over populated cities, 
contaminated land, and pollution of water resources, led to the aggravation of unexpected difficulties associated with climate change.

Half of population in Arab countries is under 25 years old, and youth unemployment rates far exceed the world average. In Egypt, where street protests forced a change in the government in early 2011 and continued to put pressure on the interim rulers continue, about $25 \%$ of college graduates cannot find full-time jobs. In Tunisia, which inspired the "Arab Spring" protesters, this figure rises to 30\%. Despite high economic performance in many Arab countries, the region lags behind other regions in the empowerment of women, despite progress in recent years.

Most countries of the region face a range of environmental challenges that deserve attention, for example, Arab region is the driest in the world, is facing many problems including water resources shortage, which affect more than $60 \%$ of its population. The United Arab Emirates, Qatar, Bahrain, and Saudi Arabia are consuming huge amounts of water resources, while Jordan and Syria exhaust their water resources, pushing for more tensions within their own countries or with neighbors. Desertification is another factor, which is accompanied by lack of water resources because of human and natural factors. Global climate change is another problem, which has increased the current difficulties faced by Arab countries on their ability, to influence in a long term, the ability of people to meet their needs. Arab countries have the largest proportion of urban pollution of all regions, because of the absolute dependence on fossil fuel compared to other countries of the world (Human Development Report, 2011).

\section{The Dilemma of Food Shortage}

Food prices have been raising sharply, in January 2011, when protests kicked off in Egypt, the World Bank's composite food price index was 29\% higher than it was in January 2010 (Kinninmont, 2011, p. 31).

Al Sharekh stated that,

Food prices in Tunisia soared in June 2010, and static salaries meant that consumers were unable to afford basic foodstuffs. Government subsidies covered only $13 \%$ of all food items, leaving the rest subject to price hikes. In Egypt "open market" policy had done little to stop the standard of living from falling for the majority of the population, with no reform policies that could bring about real economic growth and affect actual incomes on the horizon. (Al Sharekh, 2011, p. 52)

\section{The Dilemma of Water Shortage}

Yemen's water is also running out. The capital, the ancient mountain city of Sana'a with a population of 2,000,000, seems set to become the first metropolis in the world to run out of water by 2025 (Blanche, 2012, p. 26).

A report entitled "Water Security" stated that: "Water problems-when combined with poverty, social tensions, environmental degradation, ineffectual leadership, and weak political institutions - contribute to social disruptions that can result in state failure". Growing water scarcity, with highland aquifers shrinking by 10-20 feet a year, is threatening agriculture in Yemen, a country's population is 23,000,000, the World Bank says the population is exploding at an estimated $8 \%$ a year. The water problem is worsened because Yemenis use $40 \%$ of their available water to grow qat, a mildly narcotic plant. That is Yemen's largest cash crop and highly prized by Arabs across the Arabian Peninsula, far more than they allocate to grow food. A report said that worsening water shortages could cost Yemen 750,000 jobs and slash incomes by as much as $25 \%$ over the next decade (Blanche, 2012, pp. 27-28). 
Water shortages are causing a major demographic shift from the countryside to the cities and heightening the social crisis. Yemen is one of the most arid countries on the earth and relies almost exclusively on groundwater and rainfall for its water supply. The World Food Program says one fifth of the population, around 5,000,000 people, is in need of emergency food aid. Rising food and fuel prices, drought, the global economic meltdown, political instability, and years of bloodletting have all contributed to the crisis (Blanche, 2012, p. 28) (see Table 3).

Table 3

Factors Lead to Uprising and Its Impacts on Some Arab States

\begin{tabular}{|c|c|c|c|c|c|c|}
\hline & Factors & Impacts & & & & \\
\hline 1 & One ruling party & Violent & Injustice & Cruelty & Corruption & \\
\hline 2 & $\begin{array}{l}\text { High growth } \\
\text { of population }\end{array}$ & High rate of fertility & $\begin{array}{l}\text { Increased } \\
\text { population }\end{array}$ & $\begin{array}{l}\text { High rate of } \\
\text { unemployment }\end{array}$ & & \\
\hline 3 & Collapse of economy & Chronic economic crisis & $\begin{array}{l}\text { Economy } \\
\text { liberalization with } \\
\text { corruption }\end{array}$ & $\begin{array}{l}\text { Economy } \\
\text { controlled by ruling } \\
\text { party }\end{array}$ & & \\
\hline 4 & Corruption & Money laundering & Bribes & $\begin{array}{l}\text { Contracts } \\
\text { for kinship }\end{array}$ & $\begin{array}{l}\text { Increased wealth } \\
\text { of ruling class }\end{array}$ & \\
\hline 5 & $\begin{array}{l}\text { High rate of } \\
\text { unemployment }\end{array}$ & Lack of jobs & $\begin{array}{l}\text { Lack of economic } \\
\text { development }\end{array}$ & \begin{tabular}{|l} 
Collapsed \\
infrastructure
\end{tabular} & $\begin{array}{l}\text { Untrained } \\
\text { work force }\end{array}$ & \\
\hline 6 & $\begin{array}{l}\text { Spread of local } \\
\text { and regional conflict }\end{array}$ & $\begin{array}{l}\text { Regional conflict } \\
\text { (Yemen-Syria-Iraq) }\end{array}$ & $\begin{array}{l}\text { Unsafe political } \\
\text { boundaries }\end{array}$ & Local conflict & Ideology & $\begin{array}{l}\text { Human } \\
\text { trafficking }\end{array}$ \\
\hline 7 & Social injustice & Status of women & $\begin{array}{l}\text { Poor education and } \\
\text { its outputs }\end{array}$ & $\begin{array}{l}\text { Increased } \\
\text { number of poor }\end{array}$ & $\begin{array}{l}\text { Law standard of } \\
\text { living }\end{array}$ & Early marriage \\
\hline 8 & $\begin{array}{l}\text { Role of } \\
\text { modern media }\end{array}$ & Facebook, bloggers & Wiki leaks & Twitter & Cell phones & SMS \\
\hline 9 & $\begin{array}{l}\text { Emergence of } \\
\text { new personalities }\end{array}$ & Tunisia-Bo Azizi & $\begin{array}{l}\text { Egypt-Khalid } \\
\text { Said }\end{array}$ & $\begin{array}{l}\text { Yemen-Twakol } \\
\text { Kerman-Noble } \\
\text { Prize }\end{array}$ & & \\
\hline 10 & The religious factors & The role of Fridays & \begin{tabular}{|l|}
$\begin{array}{l}\text { Religion against } \\
\text { governments }\end{array}$ \\
\end{tabular} & \begin{tabular}{|l} 
Conflicts \\
among sects
\end{tabular} & & \\
\hline 11 & $\begin{array}{l}\text { Women role } \\
\text { in upspring }\end{array}$ & $\begin{array}{l}\text { Women rights in } \\
\text { social status }\end{array}$ & $\begin{array}{l}\text { Women rights in } \\
\text { social mobility }\end{array}$ & $\begin{array}{l}\text { Women rights } \\
\text { in dignified life }\end{array}$ & $\begin{array}{l}\text { Equality with men } \\
\text { in jobs and rights }\end{array}$ & \\
\hline 12 & $\begin{array}{l}\text { Dilemma of } \\
\text { food shortage }\end{array}$ & High food price & \begin{tabular}{|l|}
$\begin{array}{l}\text { Unable to afford } \\
\text { basic food stuffs }\end{array}$ \\
\end{tabular} & $\begin{array}{l}\text { Weak government } \\
\text { subsides }\end{array}$ & Poor food security & \\
\hline 13 & $\begin{array}{l}\text { Dilemma of } \\
\text { water shortage }\end{array}$ & $\begin{array}{l}\text { Poor water } \\
\text { security management }\end{array}$ & Water depletion & Water pollution & $\begin{array}{l}\begin{array}{l}\text { High water } \\
\text { consumption }\end{array} \\
\end{array}$ & Water shortage \\
\hline
\end{tabular}

\section{The Situation After Uprising}

In 2013, the Middle East and the Arab region in particular, facing greater challenges than it was during the first two years of the so-called "Arab Spring". One of the main pivotal challenges of this is the political divisions within the state itself, and the worsening scenario is the economic problem that produced significant levels of insecurity. Solutions do not look close on the horizon, but that is not impossible. More than half of the population of the Arab world, about 350,000,000 people, protesting on government corruption and abuse have not made any real change at all. Arab Spring states in transition, especially Egypt, Tunisia, Libya, and Yemen, facing various obstacles, e.g., political, economic, and security obstacles have produced mixed results so far. In Egypt, for example, during the second anniversary, Egypt is seeing many of political crises over a new constitution and deepens the gap between Islamists and secularists. Tunisia is witnessing unemployment problem and internal tensions between Islamists and secular. Libya is struggling to rein in militias and attempts to reconcile the tensions between the eastern and western regions, which threatens to tear the country apart, 
while Yemen is suffering too many, such as political, economic, social, religious, environmental problems, and accompanied by failure to achieve national reconciliation through dialogue and presenting a new constitution or parliamentary elections (Wright \& Nada, 2012, p. 1).

\section{Tunisia's Future}

Tunisia faces three major challenges in 2013: economic paralysis, the referendum on the constitution, and new elections for a permanent government for all, in addition the tensions between secularists and Islamists.

At the economic level, Tunisia is facing the problem of youth unemployment, which has the largest percentage rise in births in the world. In December 2012, unemployment rate among young Tunisians is about $40 \%$ at the national level, and unemployment rate rose to $17 \%$ from $13 \%$ since the overthrow President Zine El Abidine Ben Ali. Unemployment has reflected in November 2012 in form of violent. Tunisia is still unable to overcome the controversy over Sharia, and this issue is one of the most controversial issues in Egypt. Al Nahda, where leaders pledged to retain the 1956 constitution that set Tunisia as an Arab Muslim without reference to the role of Islam as the basis for legislation (Wright \& Nada, 2012, p. 3).

\section{Libya's Future}

In 2013, Libya was facing many problems including loss of security after the rule of Muammar Gaddafi, which lasted 42 years, the formation of a new government led by Prime Minister Ali Zaidan in October 2012, which lacked a strong power to ensure stability and rule of law. In security matter, Libya is trying to solve the problem of militias that has created during the uprising in 2011, where the government recorded more than 240,000 armed men were in 2012. Libya Government works to solve the issues of complex division of political through coordination between some of the militias and the central government. Libya Government works to solve issue of a complex division of political power in 2013, by establishment of a strong central state out of Tripoli, or decentralized power sharing where two or three areas or federation or autonomy from Tripoli. Libya, unlike other Arab countries in transition, has abundant natural resources, it contains the largest oil reserves in Africa, after political stability, and the country will be ready to start rebuilding itself in 2014 (Wright \& Nada, 2012, p. 4).

\section{Yemen's Future}

Yemen is a country in transition facing more challenges in 2013, including lack of food, sectarian conflict, tribal tensions, the Houthi separatist movement, divided army, al-Qaeda extremists, and rampant unemployment are all factors that contributed to the tearing Yemen over the past two years.

Yemen is one of the poorest countries in the Arab world, the struggle to provide food and water remained constant in 2013. Half of Yemen's 24,000,000 people are suffering from food insecurity, collapse of public services, rising food prices, failure of political situation in Yemen on national dialogue conference, to brings together the conflicting parties, southern separatists, Shiite rebels, Sunni Islamists, rival tribes, youth, and members of the former ruling party and others, all these factors will shape the future of Yemen if there is no agreement yet on the near future. Yemen is one of the most heavily armed societies in the world, and the country through its history suffering from civil wars since 1960. It is expected a civil war, involving all the various factions and tribal coalitions have been warring inside and outside if the government fails to reach a reconciliation (Wright \& Nada, 2012, pp. 5-6). 


\section{Conclusions}

As the Arab Spring states continue the long path toward democracy, it is important to reflect upon the previous year of the Arab Spring in order to better understand what actions will help to bring nature stability to the region.

Number of the experts mentioned that the process of reform in Arab countries in transition is a long process, and slow progress in an environment that requires an economic diversification including: Job creation, social equality, food and water security, and raise the standard of living, especially in Egypt, Libya, Yemen, Tunisia, and other Arab countries, factors which may lead combined or individual to future uprising.

One of the most important aspects is deterioration of food security in most Arab countries, it includes high price of food, inflation, high proportion of population who do not have enough money to buy food or face an increase in prices (Breisinger, Ecker, \& Al-Riffai, 2011, p. 1).

Many issues should be considered, improving lives of citizens that should be a top priority to support the process of any economic transformation by creating job opportunities for youth, facilitating the operations of business, particularly in field of industry, improvement of business climate, equipping young people with right skills, provision of incentives for small and medium-sized businesses in urban and rural areas. Another key issue is working to strengthen food security at national level, that requires improvements in trade agreements, logistics, and infrastructure, as well as providing support to the agriculture sector in countries with agricultural potential. In the social sector, Arab countries need to work hard and effectively to achieve social security, including provision of food subsidies for the poor, and public works programs, conditional cash transfers and remittances in kind (such as feeding programs, food aid or school), employ the unemployed and improve basic social services, especially health for women and children (Breisinger et al., 2011, p. 3).

The economic issue is highly significant and its long-term effect is critical. Almost every Arab state must develop enough economic growth to ensure employment for the young as a workforce. The Arab awakening has choked off growth. Egypt and Syria are both suffering from the same economic regression: Tourism has stopped, investments from abroad have dried up, public spending has grown with increased subsidies, and foreign currency reserves are dwindling.

There are many possible outcomes - from restoration of the old order to military takeover, from unruly fragmentation and civil war to creeping Islamisation (Eshel, 2012, p. 242).

Social justice is a top demand of Arab Spring pro-democracy movements. Those who seeking a democratic transition not only want their dictators to step down, they also want them hold accountable for the crimes they committed during the uprising and throughout their time in power (Williams \& Popken, 2012, p. $56)$.

The impact of modern technology is difficult to measure or quantify, one may point to four central parameters that will affect future developments:

(1) The army's loyalty to the regimes and its willingness to use force to oppose change;

(2) The support of the religious establishments for the regimes or their opposition to them;

(3) The willingness of the international community to intervene against the existing regimes.

For bright future, five factors should be considered, these are:

(1) Most Arab countries are ethnically, religiously, culturally, linguistically, and economically diverse. So distinct identities should be responded in any new government which created in the Middle East in general, the 
Arab countries in particular;

(2) States need to focus mainly on strengthening governments in failed states by making courts more effectively, balancing power among the executive, legislature branches, and fighting corrupting;

(3) In order to build better, transparent, democratic, and strong political and economic structures and institutions, it is very important for the Arab people to take this opportunity and take advantage of many possibilities the Arab revolt has created;

(4) The people of states have to put their hopes for a free and fair parliamentary elections, so people can move forward to a new liberal period for open politics and economic opportunity;

(5) It is very important to note that young people are the social group mostly connected by social networks and they can act in the heads of a situation like revolt. Therefore, social media can help speed up youth action and reaction toward political and economic situation.

\section{References}

Al Sharekh, A. (2011). Reform and rebirth in the Middle East. Survival, 53(2), 51-60.

Behr, T., \& Aaltola, M. (2011). The Arab uprising: Causes, prospects and implications FIIA briefing paper 76. The Finish Institute of International Affairs.

Blanche. (Ed.). (2012, June). Yemen's race against time. The Middle East, 433, 26-29.

Breisinger, C., Ecker, O., \& Al-Riffai, P. (2011). Economics of the Arab awakening: From revolution to transformation and food security. IFPRI Policy Brief, 18, 1-4.

China, W. (2011, February). The face book revolution. New African, 503, 24.

Cole, J. (2011, March 7-14). The great Arab revolt. The Nation, 10/11, 4-6.

Cortright, D. (2011). Gandhi on the Nile civil resistance on the Middle East. Commonweal, 138(5), 7-9.

Darwish, A. (2011, March). Egypt: Is the party over? The Middle East, 420, 12-14.

Egypt's Uprising. (2011, March 8). The Christian Century. Retrieved from http://www.christiancentury.org/article/ 2011-02/egypts-uprising

Eshel, D. (2012). The "Arab Spring": Turning into a long ethnic/religion war. Military Technology, 36(1), 239-243.

Failed States. (2013). The 2013 index (the annual edition).

Federation International des ligues des droit de I'Homme (FIDH). (2012). Women and the Arab Spring: Taking their place?

Fradkin, H., \& Libby, L. (2011, April). Egypt's Islamist: A cautionary tale. Commentary. Retrieved from http://www. commentarymagazine.com/article/egypts-islamists-a-cautionary-tale/

Goldstein, E. (2012, January). Before the Arab Spring, the unseen thaw. Human Rights Watch. Retrieved from http://www.world-insights.com/before-the-arab-spring-the-unseen-thaw/

Human Development Report. (2011). Human Development Report.

Ismi, A. (2011, April).Uprising a stunning blow to US control of the Middle East. The CCPA Monitor, 17(10), 16-18.

Jones, D. P. (2011a, April 18). The Arab world implodes. Will Iran now fill the vacuum? National Review, 7, 34-36.

Jones, D. P. (2011b, May 16). Syria next? The horrible Assad Regime faces its people. National Review, 9, 18-20.

Khamis, S. (2011). The Arab "Feminist" Spring? Feminist Studies, 37(3), 693.

Khan, A. A. (2012). The role social of media and modern technology in Arabs Spring. Far East Journal of Psychology and Business, 7(1), 56-63.

Kinninmont, J. (2011). Bread and Dignity. The World Today, 8/9, 31-33.

Lancaster, P. (2011, February). Tunisia: A catalyst for change? The Middle East, 419, 18-19.

Mei, X. Y. (2011). Ripples from the Arab world: Turmoil in the Middle East sparks. Global economic concerns. Beijing Review, $15,10-11$.

Nkrumah, G. (2011, March). Tunisia/Egypt-Where next? North African, 504, 8-12.

Ryan, M. (2007, May/June). State of failure. Bulletin of the Atomic Scientists, 3, 50-57.

Suarez, S. L. (2011, March). Social media and regime change in Egypt. Campaigns and Elections. Retrieved from $\mathrm{http}: / / w w w . c a m p a i g n s a n d e l e c t i o n s . c o m / p r i n t / 175972 /$ social-media-and-regime-change-in-egypt.thtml 
Vaughan, J. (2013). Arbitration in the aftermath of the Arab Spring: From uprisings to awards. The Ohio State Journal on Dispute Resolution, 28, 2.

Wambu, O. (2011, March). The Egyptian a wakening. New African, 504, 14-17.

Werrell, C. E., \& Femia, F. (Eds.). (2013, February). The Arab Spring and climate change: A climate and security correlations series he center for climate and security. Retrieved from http://americanprogress.org/issues/security/report/2013/02/28/ 54579/the-arab-spring-and-climate-change/

Wiki Leaks Was Spark to "People Power" Uprising in Tunisia. (2011, January 20-26). The New York Amsterdam News, 3, 2.

Will Libya's Unrest Affect Chinese Oil Companies' Businesses. (2011, April 6). China Chemical Reporter, 7, 7.

Williams, P. R., \& Popken, C. (B.). (2012). U.S. foreign policy and the Arab Spring: Ten short-term lessons learned. Denver Journal of International Law and Policy, 41, 1.

Women, the Revolution and the Future. (2011, March). Against the Current, 1, 11-12.

Wright, R. (2011). The Arab Spring is a jobs crisis. The Atlantic, 308(1), 58.

Wright, R., \& Nada, G. (2012, December 18). Middle East in 2013: Promise and (lots of) peril. USIP_Peace Brief, 138. Retrieved from http://www.usip.org/publications/middle-east-in-2013-promise-and-lots-peril

Yedder, O. B. (2011, February). Lessons from Tunisia's uprising. New African, 503, 20-22. 